JURNAL TEEKNNOSAINS

\title{
EFEK APLIKASI SERICIN PADA HIDROKSIAPATIT TERHADAP PERLEKATAN SEL OSTEOBLAS
}

\author{
Siti Sunarintyas \\ Fakultas Kedokteran Gigi Universitas Gadjah Mada \\ Email: sunarintyassiti@yahoo.com \\ Yeni Yustisia \\ Minat Studi Rekayasa Biomedis Sekolah Pascasarjana \\ Universitas Gadjah Mada \\ Alva Edy Tontowi \\ Jurusan Teknik Mesin dan Industri Fakultas Teknik \\ Universitas Gadjah Mada
}

\begin{abstract}
Hydroxyapatite (HA) is often used as a human bone graft. Modification of HA surface is developed to increase osseointegration process, which is influenced by cells attachment surrounded by tissue. Sericin has polar side groups that accelerate cells attachment. The aim of this research was to determine the effect of sericin application over HA surface on the attachment of osteoblast cells. The research used HA synthesized from gypsum (taken from Kulon Progo, Yogyakarta). Sericin was extracted from silkworm cocoons of Bombyx mori. Sericin of 0.01, 0.05, and $0.1 \%$ were applied over HA discs surface (10 $\mathrm{mm}$ in diameter, $3 \mathrm{~mm}$ in thickness). The discs were inserted into osteoblast cell culture of MC3T3E1 for attachment test. The data were analyzed by ANOVA and LSD. The result showed that the amount of osteoblast cells attached to HA $(7.60 \pm 0.42)$ was significantly different $(p<0.05)$ from $H A+\operatorname{sericin} 0.01 \%(10.30 \pm 0.52), H A+\operatorname{sericin} 0.5 \%$ (10.63 \pm 0.70$), H A+\operatorname{sericin} 0.1 \%(10.67 \pm 0.87)$. Variation of sericin concentrations applied over HA did not influence significant difference on the amount of cells attachment $(p>0.05)$. In conclusion, sericin application over HA surface increased the amount of osteoblast cells attachment. The concentration of sericin application over HA $(0.01,0.05,0.1 \%)$ did not influence osteoblast cells attachment.
\end{abstract}

Keywords: Hydroxyapatite, Sericin, Attachment, Osteoblast

\begin{abstract}
ABSTRAK
Hidroksiapatit (HA) banyak digunakan sebagai graf. Modifikasi permukaan HA dikembangkan untuk mempercepat oseointegrasi. Oseointegrasi dipengaruhi oleh perlekatan sel sekitar jaringan. Sericin memiliki gugus polar yang dapat meningkatkan perlekatan sel. Tujuan penelitian ini adalah melihat efek aplikasi sericin pada permukaan HA terhadap perlekatan sel osteoblas. Penelitian dilakukan menggunakan HA yang disintesis dari gipsum (Kulonprogo, Yogyakarta). Ekstrak sericin berasal dari kokon ulat sutera Bombyx mori. Sericin 0,01; 0,05; 0,1\% diaplikasikan pada permukaan disk HA (diameter $10 \mathrm{~mm}$, tebal $3 \mathrm{~mm}$ ). Disk dimasukkan ke dalam kultur sel osteoblas MC3T3E1 untuk uji perlekatan. Analisis data menggunakan anava dan LSD. Hasil penelitian menunjukkan jumlah sel yang melekat pada HA $(7,60 \pm 0.42)$ berbeda bermakna $(p<0,05)$
\end{abstract}


dengan $\mathrm{HA}+$ sericin $0,01 \%(10,30 \pm 0,52)$, $\mathrm{HA}+$ sericin $0,5 \%(10,63 \pm 0,70), \mathrm{HA}+$ sericin $0,1 \%$ $(10,67 \pm 0,87)$. Konsentrasi sericin pada pelapisan HA tidak menunjukkan perbedaan jumlah perlekatan sel $(p>0,05)$. Kesimpulan penelitian adalah aplikasi sericin pada permukaan HA meningkatkan jumlah perlekatan sel osteoblas dan konsentrasi pelapisan $(0,01 ; 0,05 ; 0,1 \%)$ tidak mempengaruhi perlekatan sel osteoblast.

Kata Kunci: Hidroksiapatit, Sericin, Perlekatan, Osteoblas

\section{Pengantar}

Tulang merupakan unsur paling penting dalam membentuk kerangka tubuh manusia. Fungsi utama tulang adalah sebagai alat penopang tubuh dan tempat melekatnya jaringan otot (Nather dkk., 2005). Tulang pada dasarnya tersusun dari protein organik berupa kolagen dan mineral anorganik berupa hidroksiapatit (Pioletti dkk., 2006). Tulang dapat mengalami kerusakan karena proses fisiologis, trauma atau penyakit (Ratner dkk., 2004). Salah satu alternatif rehabilitasi kerusakan tulang adalah penggunaan graf, yaitu aplikasi tulang baru atau material sintetik untuk mengganti tulang yang rusak. Pemakaian graf yang berasal dari tubuh pasien sendiri (autograft) maupun dari donor (allograft) mempunyai kelemahan. Adanya prosedur operasi tambahan dan kemungkinan iritasi sebagai reaksi penolakan pada pemakaian graf menyebabkan perlu dikembangkannya graf sintetik.

Rehabilitasi fraktur tulang dapat menggunakan material sintetis yang bersifat osteokonduktif. Penggunaan material osteokonduktif didasari pemikiran bahwa material osteokonduktif menstimulasi pembentukan sel menyerupai osteoblas yang mempunyai kemampuan membentuk tulang baru pada permukaan bahan. Sel osteoblas adalah diferensiasi sel pembentuk tulang yang memproduksi matriks tulang atau osteoid. Osteoblas bertanggung jawab terhadap kalsifikasi matriks tulang. Hidroksiapatit (HA) sintetis bersifat osteokonduktif meskipun sedikit menginduksi nukleasi hidroksiapatit pada tulang (Anusavice, 2009).

Hidroksiapatit dapat disintesis dari material alam diantaranya dari gipsum, koral, dan kalsit. Indonesia kaya akan kandungan material alam, salah satunya adalah gipsum yang mengelilingi perbukitan Kulon Progo. Hasil penelitian Pujianto dkk. (2006) menunjukkan bahwa serbuk hidroksiapatit dapat disintesis dari gipsum Kulon Progo (selanjutnya disebut HA-KP). Penelitian lain menunjukkan bahwa paparan HA-KP tidak berpotensi menyebabkan kematian sel (apoptosis) (Siswomihardjo dkk., 2007) dan paparan HA-KP secara sistemik per oral pada hewan coba tikus tidak bersifat toksik (Siswomihardjo dkk ${ }^{\mathrm{a}}$,2009).

Saat ini material HA sintetis yang dikembangkan untuk graf tulang masih memiliki kekurangan untuk aplikasi klinis, diantaranya : kemampuan osteokonduktif yang rendah, sulit diresorbsi, dan unsur mekanis yang rendah (Yu, 2006). Hingga saat ini para ahli terus mengembangkan modifikasi graf HA yang memiliki karakteristik menyerupai tulang dan bersifat oseointegrasi dan osteokonduksi tinggi.

Sutera alam merupakan polimer protein yang salah satunya dihasilkan oleh ulat sutera. Sumber sutera alam yang banyak dikembangkan berasal dari kokon ulat sutera Bombyx mori (gambar 1). Komponen kokon ulat sutera Bombyx mori seperti pada tabel 1. Dua jenis protein komponen utama kokon ulat sutera Bombyx mori yang terdeteksi adalah fibroin dan sericin (Kundu dkk., 2008). Sericin (20-30\%) dalam kokon ulat sutera dibuang dari fibroin selama proses manufakturing pembuatan serat sutera (Zhang, 2002). Sericin bersifat hidrofilik, terdiri dari 18 asam amino (tabel 2) yang mengandung gugus polar seperti hidroksil, karboksil, amino serta banyak mengandung serin (Kundu dkk., 2008). 


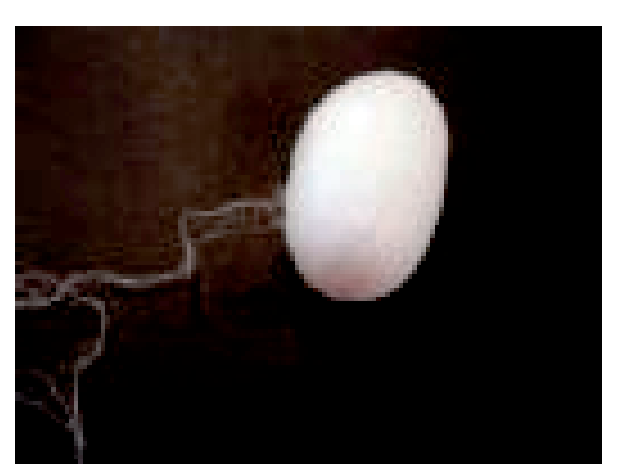

Gambar 1

Kokon ulat sutera Bombyx mori

Tabel 1

Komponen sutera alam Bombyx mori (Mondal dkk., 2007)

\begin{tabular}{ll}
\hline Komponen & Persen \\
\hline Fibroin & $70-80$ \\
Sericin & $20-30$ \\
Malam & $0,4-0,8$ \\
Karbohidrat & $1,2-1,6$ \\
Bahan anorganik & 0,7 \\
Pigmen & 0,2 \\
\hline Total & 100 \\
\hline
\end{tabular}

Tabel 2

Komposisi asam amino sericin

\begin{tabular}{ll}
\multicolumn{2}{c}{ (Terada dkk., 2005) } \\
\hline Asam amino & Persen molar \\
\hline Asam aspartat & 18,0 \\
Treonin & 8,4 \\
Serin & 32,2 \\
Asam glutamat & 4,6 \\
Prolin & 0,6 \\
Glisin & 15,7 \\
Alanin & 5,3 \\
Sistin & $<0,05$ \\
Valin & 3,6 \\
Metionin & 0,05 \\
Isoleusin & 0,7 \\
Leusin & 1,1 \\
Tirosin & 3,7 \\
Fenilalanin & 0,4 \\
Histidin & 1,3 \\
Lisin & 2,5 \\
Arginin & 1,8 \\
\hline
\end{tabular}

Sericin bersifat biokompatibel. Penelitian Sunarintyas dkk. (2009) menunjukkan bahwa sericin dari kokon ulat sutera liar Cricula tripehenestrata yang banyak ditemukan di hutan Pulau Jawa tidak bersifat sitotoksik terhadap biakan sel fibroblas gingiva manusia. Penelitian Siswomihardjo dkk.' (2009) menunjukkan bahwa sericin dari limbah kokon ulat sutera Bombyx mori dari Industri Sutera Alam tidak bersifat toksik pada hewan coba tikus pada pemeriksaan darah, organ hati dan ginjal. Berdasarkan uji biokompatibilitas tersebut, sericin berpotensi digunakan sebagai biomaterial dalam rekayasa jaringan tulang.

Takeuchi dkk. (2005) menunjukkan bahwa sericin efektif menginduksi nukleasi HA sebagai matriks anorganik tulang. Sericin dapat dicampur, kopolimerisasi, atau cross linked dengan material lain menghasilkan material dengan karakteristik yang lebih baik. Penelitian Zhang dkk. (2008) menunjukkan bahwa modifikasi permukaan titanium menggunakan sericin meningkatkan adhesi dan proliferasi osteoblas serta kenaikan aktivitas alkali fosfatase.

Meyer dkk. (2005) mengatakan bahwa proses interaksi sel terhadap material bersifat dinamis dan tergantung pada beberapa parameter yang mempengaruhi respon sel. Perlekatan sel tergantung pada karakteristik permukaan material seperti sifat hidrofilisitas, kimiawi, muatan topografi dan kepadatan. Penelitian Liu dkk. (2007) menunjukkan bahwa adhesi osteoblas berkorelasi dengan sifat pembasahan permukaan material. Korelasi tinggi diperoleh pada permukaan relatif hidrofilik. Di lain fihak Lee dkk. (1994) menunjukkan bahwa gugus asam karboksilat menaikkan perlekatan dan proliferasi sel sehubungan dengan meningkatnya pembasahan.

Berdasarkan latar belakang masalah, direncanakan penelitian dengan tujuan mengetahui efek aplikasi sericin pada permukaan HA sebagai graf tulang terhadap perlekatan sel osteoblas. Hasil 
penelitian yang diperoleh diharapkan bermanfaat dalam pengembangan graf sintetik dengan karakteristik sifat mirip tulang alami (osteokonduktivitas tinggi), mudah diperoleh (menggunakan bahan lokal), dan murah (teknologi lokal).

\section{Bahan dan Metode}

Bahan penelitian yang digunakan adalah : kokon ulat sutera Bombyx mori, $\mathrm{Na}_{2} \mathrm{CO}_{3}$ 0,02M, akuades, alkohol 75\%, serbuk HA hasil sintesis gipsum Kulon Progo, bahan kultur sel (medium alva MEM, FBS, penisilin, streptomisin, 0,25\% tripsin-EDTA), $\mathrm{NaOH} 1 \mathrm{M}, \mathrm{HCl} 0,1 \mathrm{~N}$, sel osteoblas (MC3T3E1), PBS, NHS, EDAC. Alat penelitian yang dipakai adalah: perangkat kompaksi HA, mesin sintering, in kubator, rotary evaporator, hemositometer, sentrifus, timbangan, mikropipet, mikroskop inverted, plat sumuran-24, kamera digital. Prosedur penelitian dilakukan dengan urutan : pembuatan disk HA, ekstraksi sericin, aplikasi sericin pada permukaan HA, kultur sel osteoblas, dan uji perlekatan sel. Penelitian dilakukan di LPPT, UGM, Yogyakarta.

Pembuatan disk HA dilakukan dengan menimbang serbuk HA 0,4 gram dimasukkan ke dalam cetakan kompaksi. Cetakan diletakkan pada alat kompaksi kemudian dilakukan penekanan sebesar 120 Mpa. Hasil cetakan adalah sampel penelitian berbentuk disk dengan diameter $10 \mathrm{~mm}$ dan tebal $3 \mathrm{~mm}$. Sampel HA disintering pada suhu $1450^{\circ} \mathrm{C}$ selama 2 jam.

Ekstraksi sericin dilakukan sesuai cara Terada dkk. (2002) sebagai berikut : kokon ulat sutera Bombyx mori 50 gram ditambah akuades $1 \mathrm{ml}$ dan 5 gram $\mathrm{Na}_{2} \mathrm{CO}_{3}$ $(0,02 \mathrm{M})$ direbus selama 1 jam. Hasil rebusan disaring, ampas yang diperoleh dibuang. Filtrat yang diperoleh dikeringkan dalam inkubator pada suhu $50^{\circ} \mathrm{C}$ (2 hari). Filtrat dilarutkan dalam alkohol 75\%, di stiring 15 menit, didiamkan 24 jam. Filtrat disaring, diperoleh filtrat (sericin) dan ampas. Ampas dicampur dengan alkohol 75\%, distiring 15 menit, didiamkan 24 jam kemudian dicampur dengan filtrat yang diperoleh. Filtrat yang didapat diuapkan menggunakan rotary evaporator hingga diperoleh filtrat kental. Filtrat kental dikeringkan menggunakan freeze dryer. Ekstrak sericin yang diperoleh dilarutkan dalam akuades hingga diperoleh konsentrasi 0,01, 0,5, 0,1\%.

Aplikasi sericin pada HA dilakukan dengan modifikasi cara Zhang dkk. (2008). Hidroksiapatit diletakkan dalam larutan 1 $\mathrm{M} \mathrm{NaOH}$, suhu $50^{\circ} \mathrm{C}$ selama 1 jam kemudian dicuci menggunakan $0,1 \mathrm{~N} \mathrm{HCl}$ dan akuades pada suhu kamar. Hidroksiapatit dipreaktivasi selama 1 jam dalam larutan PBS yang mengandung 1 $\mathrm{mg} / \mathrm{ml}$ NHS dan $10 \mathrm{mg} / \mathrm{ml}$ EDAC pada suhu kamar. Hidroksiapatit dilapisi sericin dan dibiarkan selama 6 jam pada suhu kamar. Selanjutnya HA yang diberi aplikasi sericin disebut sebagai HS.

Cell line osteoblas MC3T3E1 mouse yang diperoleh dari Universitas Tokushima, Jepang, dikultur pada media alva MEM dengan suplementasi 10 \% FBS, $100 \mathrm{U} / \mathrm{mL}$ penisilin, $100 \mathrm{mg} / \mathrm{mL}$ streptomisin. Sel diinkubasi pada suhu $37^{\circ} \mathrm{C}$ dengan kadar $\mathrm{CO}_{2} 5 \%$. Media diganti setiap 48 jam. Kultur sel dilepas menggunakan teknik tripsinisasi $(0,25 \%$ tripsin dalam EDTA), disuspensi dalam medium kultur baru dan digunakan untuk uji perlekatan sel.

Perlekatan osteoblas pada hidroksi apatit - sericin (HS) dievaluasi dengan menghitung jumlah sel yang melekat 


\section{SITI SUNARINTYAS, YENI YUSTISIA, DAN ALVA EDY TONTOWI EFEK APLIKASI SERICIN PADA HIDROKSIAPATIT TERHADAP PERLEKATAN SEL OSTEOBLAS}

menggunakan metode adaptasi Zhang dkk.(2008) dan Rice University (2009). Disk HS diinkubasi dalam plat sumuran-24 yang mengandung kepadatan sel $50.000 \mathrm{sel} / \mathrm{cm}^{3}$. Setelah 4 jam inkubasi, disk dicuci menggunakan PBS untuk menghilangkan sel yang tidak melekat. Sel yang melekat pada disk dilepas menggunakan tripsin dan dihitung jumlahnya menggunakan hemositometer.

\section{HASIL DAN PEMBAHASAN}

Hasil pengukuran rerata dan simpang baku perlekatan sel osteoblas pada permukaan hidroksiapatit yang dilapisi sericin pada berbagai konsentrasi seperti pada tabel3.

Tabel 3

Rerata dan simpang baku perlekatan sel osteoblas

\begin{tabular}{ll}
\hline Grup Material & Jumlah sel $\left(\times 10^{3}\right)$ \\
\hline HA & $7,60 \pm 0.42$ \\
HA + sericin $0,01 \%$ & $10,30 \pm 0,52$ \\
HA + sericin $0,5 \%$ & $10,63 \pm 0,70$ \\
HA + sericin 0,1\% & $10,67 \pm 0,87$ \\
\hline
\end{tabular}

Tabel 3 menunjukkan bahwa pelapisan sericin pada HA meningkatkan jumlah sel osteoblas yang melekat. Semakin tinggi konsentrasi persen pelapisan HA, jumlah sel osteoblas yang melekat pada disk cenderung meningkat. Untuk mengetahui kemaknaan efek aplikasi sericin pada permukaan HA dilakukan uji statistik analisis varian satu jalur seperti pada tabel 4 .

Tabel 4

Ringkasan analisis varian jumlah perlekatan sel osteoblas

\begin{tabular}{llllll}
\hline \multicolumn{1}{c}{$\begin{array}{c}\text { Sumber } \\
\text { variasi }\end{array}$} & $\begin{array}{c}\text { Jumlah } \\
\text { Kuadrat }\end{array}$ & $\begin{array}{c}\text { Derajat } \\
\text { bebas }\end{array}$ & $\begin{array}{c}\text { Rerata } \\
\text { Kuadrat }\end{array}$ & F & p \\
\hline $\begin{array}{l}\text { Antar } \\
\text { kelompok }\end{array}$ & 19,61 & 3 & 6,54 & 12,84 & 0,002 \\
$\begin{array}{l}\text { Dalam } \\
\text { kelompok }\end{array}$ & 4,07 & 8 & 0,51 & & \\
Total & 23,68 & 11 & & & \\
\hline
\end{tabular}

Tabel 4 menunjukkan bahwa ada perbedaan yang bermakna antara grup perlakuan aplikasi sericin pada HA. Liu dkk. (2009) mengatakan bahwa fase perlekatan awal sel pada biomaterial tidak melibatkan adsorpsi protein spesifik tetapi lebih didominasi oleh kekuatan fisik antara sel dan biomaterial. Hasil penelitian Cui dkk. (2003) menunjukkan bahwa pelapisan chitosan pada permukaan PLLA meningkatkan pembasahan permukaan PLLA dan meningkatkan perlekatan dan proliferasi sel. Berdasarkan hal ini tampaknya permukaan HA yang dilapisi sericin bersifat lebih hidrofilik dari pada permukaan HA yang tidak dilapisi sericin sehingga menyebabkan perlekatan sel lebih banyak. Protein sericin dari kokon ulat sutera Bombyx mori terdiri dari beberapa polipeptida yang mengandung sebagian besar komponen serin, asam aspartat, dan glisin. Sekuensi asam amino spesifik Arg-Gly-Asp (RGD) yang bersifat meningkatkan perlekatan sel (Liu dkk., 2007) tidak dijumpai pada sericin Bombyx mori. Berdasarkan hal tersebut diperkirakan bahwa perlekatan sel osteoblas pada HS bukan berdasarkan interaksi spesifik melalui reseptor, melainkan mungkin terutama dari interaksi nonspesifik yang berhubungan dengan sifat hidrofilisitas dan gugus fungsional sericin. Permukaan hidroksiapatit yang dilapisi sericin mempunyai sifat hidrofilik yang meningkat yang menyebabkan sel osteoblast banyak melekat,

Kemungkinan lain dari peningkatan jumlah sel yang melekat pada permukaan HS berhubungan dengan gugus fungsional yang terdapat pada permukaan HS. Sericin mengandung gugus polar hidroksil, karboksil dan amin. Gugus amin bermuatan positif. Pada umumnya sel bermuatan negatif. Sel osteoblas yang bersifat negatif akan melekat pada permukaan HS positif karena adanya interaksi elektrostatik. Gugus hidroksil pada permukaan HS meningkatkan perlekatan sel kemungkinan karena adanya ikatan hidrogen antara HS dan gugus polar permukaan sel. Gugus karboksil memberikan efek perlekatan sel kemungkinan karena sifat pembasahannya (Lee dkk., 1994). Zhang dkk. (2008) mengatakan bahwa efek imobilisasi sericin pada material adalah adanya peningkatan adhesi. Efek ini lebih disebabkan 
karena sifat bioaktif sericin daripada sifat hidrofobisitasnya.

Untuk mengetahui lebih lanjut efek konsentrasi sericin terhadap perlekatan sel osteoblas pada HA dilakukan analisis LSD. Hasil analisis LSD seperti pada tabel 5.

Tabel 5

Ringkasan uji LSD jumlah perlekatan sel osteoblas

\begin{tabular}{llc}
\hline \multicolumn{1}{c}{ Sumber Perbedaan } & $\begin{array}{c}\text { Perbedaan } \\
\text { rerata }\end{array}$ & $\mathrm{p}$ \\
\hline $\begin{array}{l}\text { HA dan HA + sericin } \\
0,01 \%\end{array}$ & 2,70 & 0,002 \\
$\begin{array}{l}\text { HA dan HA + sericin } \\
0,5 \%\end{array}$ & 3,03 & 0.001 \\
$\begin{array}{l}\text { HA dan HA + sericin } \\
0,1 \%\end{array}$ & 3,07 & 0.001 \\
$\begin{array}{l}\text { HA + sericin 0,01\% dan } \\
\text { HA + sericin 0,5\% }\end{array}$ & 0,33 & 0,583 \\
$\begin{array}{l}\text { HA + sericin 0,01\% dan } \\
\text { HA + sericin 0,1\% }\end{array}$ & 0,37 & 0,547 \\
$\begin{array}{l}\text { HA + sericin 0,5\% dan } \\
\text { HA + sericin 0,1\% }\end{array}$ & 0,03 & $0,95 S$ \\
\hline
\end{tabular}

Tabel 5 menunjukkan bahwa ada perbedaan bermakna $(p<0,05)$ antara jumlah sel osteoblas yang melekat pada permukaan HA dan $\mathrm{HA}+$ sericin baik pada pelapisan sericin 0,$01 ; 0,5$; atau $0,1 \%$. Tidak ada perbedaan yang bermakna $(p>0,05)$ antara jumlah sel osteoblas yang melekat pada permukaan HA yang dilapisi sericin pada semua pelapisan variasi konsentrasi sericin. Hal ini mungkin dikarenakan konsentrasi sericin yang diaplikasikan pada permukaan HA berada di atas konsentrasi efektif. Berdasarkan hal tersebut perlu dilakukan penelitian tentang pengaruh konsentrasi aplikasi sericin pada permukaan HA dibawah konsentrasi 0,01\%.

\section{SIMPULAN}

Berdasarkan hasil penelitian yang telah dilakukan dapat disimpulkan bahwa aplikasi sericin pada permukaan HA meningkatkan jumlah perlekatan sel osteoblas. Konsentrasi aplikasi sericin sebesar 0,01, 0,05, dan 0,1\% pada permukaan HA tidak memberikan perbedaan yang bermakna terhadap jumlah perlekatan sel osteoblas.

\section{Daftar Pustaka}

Anusavice KJ (2009) Phllip's Science of Dental Materials, edisi 11. Philadelphia: WB Saunders Co, 62-6.

Cui YL, Qi AD, Liu WG, Wang XH, Wang H, Ma DM and Yao KD (2003) Biomimetic surface modification of Poly(L-lactic acid) with chitosan and its effects on articular chondrocytes in vitro. Biomaterials 24: 3859-68.

Kundu SC, Dash BC, Dash R and Kaplan DL (2008) Natural protective glue protein, serecin bioengineered by silkworm: potential for biomedical and biotechnological applications. Progress in Polym Sci33: 998-1012.

Lee JH, Jung HW, Kang I and Lee HB (1994) Cell behavior on polymer surfaces with different functional groups. Biomaterials 15(9): 705-11.

Liu X, Lim JY, Donahue HJ, Dhurjati R, Mastro AM and Vogler EA (2007) Influence of substratum surface chemistry/energy and topography on the human fetal osteoblastic cell line hFOB1.19: Phenotypic and Genotypic responses observed in vitro. Biomaterials 28(31): 4535-50.

Liu Z, Zhuge Y and Velazquez OC (2009) Trafficking and differentiation of mesenchymal stem cells. J Cell Biochem 106: 984-91.

Meyer GJ, de Bruijn JD, Koole R, and Van Blitterswijk CA (2005) Cell-based bone tissue engineering. PLoS Med 4: 9. 
Mondal M, Trivedy K and Kumar SN (2007) The silk proteins, sericin and fibroin in silkworm, Bombyx mory Linn. A review, Caspian Jenv Sci5(2): 63-76.

Nather A, Ong HJC and Aziz Z (2005) Bone grafts and bone substitute, Philadelphia: Imperial College Press, 3 - 11.

Pioletti DP, Montjovent MO, Zambelli PY and Applegate L (2006) Bone tissue engineering using fetal cell therapy. Swiss MedWkly 136: 557-560.

Pujianto E, Siswomihardjo W, Ana IA, Tontowi AE and Wildan W (2006) Cytotoxicity of hydroxy apatite from local gypsum. Bandung: Dipresentasikan pada temu ilmiah BME Days.

Ratner BD, Hoffman AS, Schoen FJ and Lemons JE (2004) Biomaterials Science - An Introduction to Materials in Medicine, edisi ke2. Amsterdam: Elsevier, hal 1-3.

Rice University (2009) Tissue engineering laboratory protocol. Tersedia pada: http:// www.ruf.rice.edu/ `bioslabs / methods/microscopy/cellcounting.html

Siswomihardjo W, Sunarintyas S dan Tontowi AE (2007) Effect of synthetic hydroxyapatite on apoptosis of human fibroblast. Kuta Bali : Dipresentasikan pada pertemuan IADR - International association of Dental Research.

Siswomihardjo W, Sunarintyas S dan Tontowi $\mathrm{AE}^{\mathrm{a}}$ (2009) Histopathological examination of the toxicity of locally synthesized hydroxyapatite, Wuhan, China: Dipresentasikan pada pertemuan IADR International Association of dental research meeting.

Siswomihardjo W dan Sunarintyas $S^{\mathrm{b}}$ (2009) Pemanfaatan serecin dalam limbah industri sutra alam lokal sebagai biomaterial.
Yogyakarta: Laporan penelitian RUSNAS

- Riset Unggulan Strategis Nasional UGM.

Sunarintyas S dan Amanda J (2009) Uji sitotoksisitas ekstrak kepompong ulat sutera liar (Cricula triphenestrata) pada biakan sel fibroblast gingival. Yogyakarta: laporan penelitian dana masyarakat FKGUGM.

Takeuchi A, Ohtsuki C, Miyazaki T, Kamitakahara M, Ogata S, Yamazaki M, Furutani $Y$, Kinoshita $\mathrm{H}$ and Tanihara M (2005) Heterogenous nucleation of hydroxyapatite on protein : structural effect of silk sericin. J $R$ Soc Interface 2(4) : 373-8.

Terada S, Nishimura T, Sasaki M, Yamada H and Miki M (2002) Sericin - a protein derived from silkworms, accelerates the proliferation of several mammalian cell lines including a hybridoma Cytotechnology 40:3-12.

Terada S, Sasaki M, Yanagihara K and Yamada H (2005) Preparation of silk protein sericin as mitogenic factor for better mammalian cell culture. J Biosci and Bioeng 100(6): 667-71.

Yu E (2006) Bioreactor-based bone tissue engineering: The influence of dynamic flow on osteoblast phenotypic expression and matrix mineralization. PNAS 101 (31) :11203-8.

Zhang F, Zhang Z, Zhu X, Kang E and Neoh K (2008) Silk functionalized titanium surfaces for enhancing osteoblast functions and reducing bacterial adhesion. Biomaterials 29:4751-59.

Zhang YQ (2002) Application of natural silk protein sericin in biomaterials. Biotech. Adv 20:91-100. 